\title{
Deploying Engineering-Based Learning in High School Students STEM Learning
}

\begin{abstract}
By Abe Zeid ${ }^{*}$
Teaching STEM concepts to today's high school students has been challenging. Span of attention is short. Students are glued to their electronic devices. They cannot appreciate the abstract method of teaching, meaning covering concepts followed by solving problems from a textbook. Research has shown that students become excited and motivated to learn STEM abstract concepts when they are related to their daily lives as applied to products and devices. Acknowledging this research finding, the question is how to change the traditional high school teaching approach to incorporate hands-on problem solving? Before we answer this question, we must bear in mind the many academic school year challenges and constraints. First, the curriculum is jammed. There is no room to add new courses. Second, it is hard to add new content to courses. Teachers must prepare students to take mandated standardized tests. Third, schools operate on tight budgets, making it hard to buy materials and supplies for student projects. One common teaching method that overcome these challenges and allow students hands-on experience is problembased learning (PBL). A teacher using PBL assigns the students in class an open-ended problem that focuses on some STEM concepts. Students research the problem and solve it. The main advantage of PBL is that it helps students solve open-ended problems. It allows a teacher to assign a class an ill-defined problem to solve using STEM concepts. Typically, there is no one solution to such kind of a problem, unlike a science-based problem that has only one closed-form solution. The author has conceived, implemented, and tested an alternative method for PBL. It is EBL; engineering-based learning. EBL has the same spirit as PBL but it has its roots in engineering design. It is the structural nature of EBL that makes it easy and systematic to use in STEM classrooms. The structure is based on the well-known engineering design process. The paper discusses EBL in more details.
\end{abstract}

Keywords: Engineering-based Learning (EBL), Engineering Design Process (EDP), Open-ended problems, STEM.

\section{Introduction}

STEM (Science, technology, Engineering, Mathematics) subjects have been traditionally hard to teach to school students in all grades. The traditional method of instructions is as follows. Teachers develop their lesson plans. They use a textbook. They deliver the lecture in class to students. They solve examples in the classroom and assign problems from the back of the textbook.

This model of teaching has eroded over time and is very much ineffective in

"Professor and Director, CAD/CAM Program, MIE Department, Northeastern University, USA. 
todays learning, due to many reasons. Today's students grow in different environments and use different daily tools and technologies that were not available decades ago. Electronic tools from computers to cell phones have forged students to use the tools more than thinking about them. Thus, we need to develop new pedagogical methods that fit the learning styles of the students to entice them to pursue STEM careers.

Current STEM teaching methodologies are shown to be ineffective in sustaining long-term interest among school students since they focus on memorizing the theory without providing enough technical integration with realworld applications. A possible solution to alleviate traditional lecture-based approaches is through real-world design challenges.

One method that gained popularity for STEM teaching is PBL. PBL is defined as group learning method to solve challenging problems and had emerged as an incremental innovation in teaching pedagogy that past research has extensively documented its corresponding benefits. Further, PBL has shown the benefits of more experiential learning in school classrooms. A similar method is challenge-based learning (Ktoridou \& Doukanari, 2016, p. 61 - 71; YESICT EU project, 2018). It is almost identical to PBL, but a different name.

An alternative method to PBL is EBL. EBL has its roots in engineering design courses taught at college level. The core of these courses are capstone design projects. Capstone design projects present a culmination experience for college engineering students in ABET accredited engineering programs in the US (Dym, Agogino, Eris, Frey, \& Leifer, 2005, p. 103 - 120). Students work on open ended projects sponsored by faculty advisors and/or industry. These projects are open ended and could result in patents as well as start-ups. Students work in groups, typically of 4 students for one semester. They present their designs and prototypes to a panel of judges who select the best projects for certificate awards.

What makes these projects successful is the structured engineering design process, shown in Figure 1, that students follow. All students follow the 8 steps shown in Figure 1 regardless of the details of their project. These steps are very important as they focus the students activities in their quest to solve the design problem at hand.

Figure 1. Engineering Design Process (EDP)

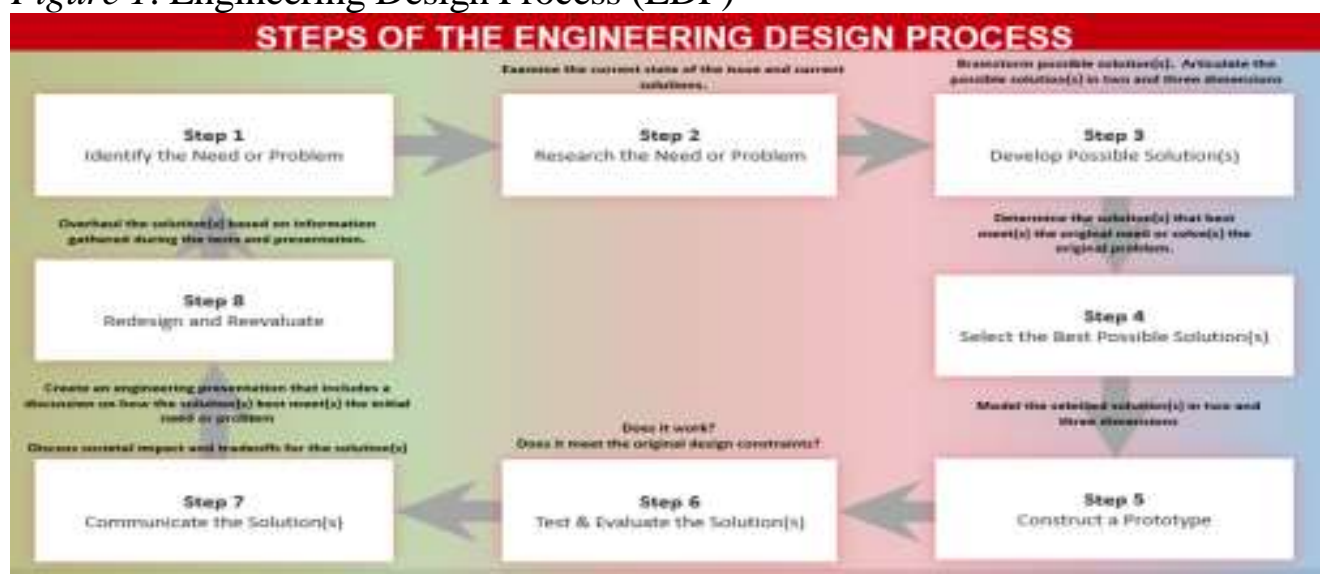


As more engineering faculty take on STEM research, they began to use their design thinking in helping high school students and teachers to learn and deploy EDP in their STEM courses.

\section{Literature Review}

The research reported in this paper is motivated by national and local needs for STEM/IT workforce and professional development for teachers. The Bureau of Labor Statistics identified IT as the U.S. economy's fastest growing industry (Berman, 2001) for the 2000-10 period. The US Labor Department echoes similar needs (1991, 2000). In Massachusetts, similar observations are made by Boston Redevelopment Agency (BRA, 2001). Regarding professional development of teachers, the National Research Council's (NRC, 2001) reports that "... most teachers lack the professional development and support (e.g., training and release time) needed to incorporate information technology into daily instruction, and as a result, significant numbers of such teachers either ignore the pedagogical uses of technology or use technology ineffectively." Gatta (2001) and Winschitl (2002) have documented the need for allocating more resources for professional development of teachers rather than for just acquiring more computer soft-ware and hardware.

When it comes to the state, Massachusetts Science and Technology/ Engineering Curriculum Framework (Massachusetts, 2003) requires school districts to follow and implement statewide guidelines for teaching, learning, and assessment in science and technology/engineering. All Massachusetts school districts face the challenge of meeting these framework requirements.

Reporting on underrepresented groups for STEM career, the National Research Council (NRC, 2001) characterized the current IT workforce as "predominantly white, male, young, educated, and U.S. born." Gatta (2001; Gatta $\&$ Trigg, 2001) has documented the reasons for such imbalance and traces it back to loss of interest in STEM courses among school girls and underrepresented students. Without a core group of girls in STEM classes, female students are at risk of social isolation in the classroom (American Association of University Women, 2000) and not participating in the IT workforce (CIO Insight, 2007; Daley, 1998).

Both girl and African-American and Hispanic-American are most likely to find project-based learning model quite appealing (Hale-Benson, 1986). According to the report "New Formulas for Ameri-ca's Workforce: Girls in Science and Engineering," girls respond positively to hands-on activities (NSF, 2003). Girls of all ages like their math and science to be useful and relevant to their everyday lives. Furthermore, girls prefer clubs, communities, and face-toface interactions to independent study. Research has shown that traditional classroom instruction methods likewise may fail to engage African-American and Hispanic-American students (Guild, 2001). To a greater degree than their classmates, underrepresented students respond to learning experiences that emphasize oral skills, physical activity, and strong personal relationships (Shade, 
1989; Hilliard, 1989). As a result, collaboration, discussion, and active projects in the classroom tend to be more engaging for minority students than work involving independent study and competition (Guild, 2001).

\section{Methodology}

The Engineering Based Learning (EBL) methodology is summarized as follows. Engineering faculty and high school teachers work together during summer when teachers are off. The engineering faculty educates and introduces the teachers to EBL. EBL is contrasted against PBL so teachers can understand it quickly. Teachers are then introduced to sample engineering projects. Finally, teachers are requested to map EBL to their classroom teaching by modifying their lesson plans for one course to incorporate EBL and define an open ended design project for the class students. The details of EBL follows.

We use the engineering design process (EDP) commonly used at universities and delineated in the Massachusetts Framework (Massachusetts, 2003) as the basis for teachers' professional development and for formulating students' capstone projects. Working on their project in accordance with EDP steps, students will deliver the problem solution in the form of prototypes, reports, and presentations.

The pedagogical framework to implement project design principles and deliver instructions for both teachers and students are based on the following research on learning in two areas:

Table 1. Learning Pedagogy

\begin{tabular}{|l|l|}
\hline Area & \multicolumn{1}{|c|}{ Pedagogy } \\
\hline $\begin{array}{l}\text { Professional } \\
\text { development models } \\
\text { (Conley, Ressler, } \\
\text { Lenox, \& Samples, } \\
\text { 2000, p. 31-38, Dennis, } \\
\text { 2001, p. 24-27) }\end{array}$ & $\begin{array}{l}\text { The project team will use the T4E (Teaching Teachers to Teach } \\
\text { Engineering) teaching model developed and conducted by the } \\
\text { successors ExCEEd (Excellence in Civil Engineering } \\
\text { Education) and ExcEEd (Excellence in Engineering Education) } \\
\text { were offered during 1999-2004. The key features of T4E } \\
\text { model include active learning, learning objectives, content } \\
\text { organization, clear expectations, lesson planning, effective } \\
\text { delivery, and teaching styles variation. }\end{array}$ \\
\hline $\begin{array}{l}\text { Project-based learning } \\
\text { model (Shade, 1989, p. } \\
\text { 137-155; AAUW, 2000) }\end{array}$ & $\begin{array}{l}\text { This approach offers many benefits to students. They gain } \\
\text { deeper knowledge of subject matter, show increased self- } \\
\text { direction and motivation, and acquire improved research and } \\
\text { problem-solving skills. They feel of more responsibility for and } \\
\text { control over their own learning. }\end{array}$ \\
\hline
\end{tabular}

The EBL curriculum adopts and adapts an existing innovative STEM/IT course curriculum entitled as "Engineering the future (EtF): Designing the World of the $21^{\text {st }}$ Century." This course has been developed by NCTL (National Center for Technological Literacy) at Boston MoS. NCTL has successfully led professional development. 
Table 2. EBL Course Material

\begin{tabular}{|l|l|}
\hline $\begin{array}{l}\text { Course } \\
\text { Material }\end{array}$ & \multicolumn{1}{c|}{ Description } \\
\hline $\begin{array}{l}\text { The Engineer's } \\
\text { Notebook }\end{array}$ & $\begin{array}{l}\text { The notebook guides students in the laboratory studies. It mimics the } \\
\text { way engineers undertake projects in practice: learn the concepts and } \\
\text { acquire the skills required to successfully complete the projects, and } \\
\text { report their research, testing, and final solutions. }\end{array}$ \\
\hline The Textbook & $\begin{array}{l}\text { The book is written by practicing engineers. Men and women, from } \\
\text { various ethnic and cultural backgrounds, tell what it is like to practice } \\
\text { their profession and how they came to do what they do. }\end{array}$ \\
\hline $\begin{array}{l}\text { The Teacher's } \\
\text { Guide }\end{array}$ & $\begin{array}{l}\text { The guide provides detailed recommendations for presenting project- } \\
\text { based learning pedagogy and laboratory activities to students and for } \\
\text { leading classroom discussions. The Guide also provides connections to } \\
\text { educational standards, a list of laboratory supplies, and background } \\
\text { science reading. }\end{array}$ \\
\hline
\end{tabular}

The EBL methodology does not necessarily require the introduction of an additional new course in high schools. Instead, EBL can be incorporated into an existing courses or after-school program. School districts have the flexibility to adapt EBL material to fit their specific needs by selecting the modules and projects that fits their students' the best.

The teachers training provides an intensive, two-week workshop for 20 teachers every summer. It provides 80 hours of professional development for each participating teacher. At these workshops, teachers will learn to implement the EBL model. Further, each teacher gets 40 hours of contact time in follow-up sessions through the school year.

- Week 1 Teacher Training: In week 1, teachers will learn the fundamentals of technology, EDP, project-based learning pedagogy, and teamwork. The instruction is divided as follows:

Table 3. Week 1 Training Themes

\begin{tabular}{|l|l|}
\hline Day & \multicolumn{1}{|c|}{ Theme and Brief Description } \\
\hline Day 1 & $\begin{array}{l}\text { STEM workforce Overview: We engage guest speakers to share with teachers } \\
\text { how engineering and STEM is put into practice. We invite industry partners to } \\
\text { provide overview of selected products from nanotechnology and sensing } \\
\text { technology. }\end{array}$ \\
\hline Day 2 & $\begin{array}{l}\text { Engineering Design Process (EDP): We cover the steps of EDP, its } \\
\text { application to engineering problems solving, and illustrate the process by } \\
\text { designing a cell phone holder }\end{array}$ \\
\hline Day 3 & $\begin{array}{l}\text { CAD (Computer Aided Design) Modeling: We cover basic concepts to sketch } \\
\text { design models, create drawings, and render 3D design models }\end{array}$ \\
\hline Day 4 & Nanotechnology: We cover the basic concepts of nanotechnology \\
\hline Day 5 & Sensing technology: We cover the basic concepts of sensing technology \\
\hline
\end{tabular}

The activities for each day consist of a mix of presentations, hands-on activities, and discussions. For example, Table 4 shows the schedule for Day 2: 
Table 4 Schedule for Day 2

\begin{tabular}{|c|c|}
\hline 9:00-9:15 & Comment cards from Day 1 \\
\hline $\begin{array}{l}9: 15- \\
10: 45\end{array}$ & Introduction to the EDP: • IDEO Video. • Quick-build cell phone holder \\
\hline $\begin{array}{l}10: 45- \\
11: 00\end{array}$ & Break \\
\hline $\begin{array}{l}11: 00- \\
11: 30\end{array}$ & $\begin{array}{l}\text { Compare Design and Inquiry: } \bullet \text { Reflections on activity. } \bullet \text { Design and Inquiry } \\
\text { side-by-side }\end{array}$ \\
\hline $\begin{array}{l}11: 30- \\
12: 00\end{array}$ & $\begin{array}{l}\text { Reflect on EDP: } \bullet \text { Outline the cell phone holder designs created by each team. } \\
\text { - Explain the EDP steps. } \cdot \text { Illustrate the EDP steps using the holder design }\end{array}$ \\
\hline $\begin{array}{l}12: 00- \\
12: 45\end{array}$ & Lunch \\
\hline $\begin{array}{l}12: 45- \\
1: 15\end{array}$ & $\begin{array}{l}\text { Teamwork: } \bullet \text { Personal experience of a teacher. } \bullet \text { Importance of teamwork. } \bullet \\
\text { Forming teams for organizer project. } \bullet \text { Organizer challenge }\end{array}$ \\
\hline 1:15-2:30 & $\begin{array}{l}\text { Organizer Activity: } \bullet \text { Teams identify projects. } \bullet \text { Build mock-up. } \bullet \text { Report } \\
\text { results. }\end{array}$ \\
\hline $2: 30-2: 45$ & Break \\
\hline $2: 45-3: 15$ & $\begin{array}{l}\text { Project Based Learning Resources: • Course Modules. • TEC Reviews - } \\
\text { online. • ERC in the Museum's Library. }\end{array}$ \\
\hline $3: 15-3: 45$ & Engineering Scheduling \& Tracking \\
\hline $3: 45-4: 00$ & Comment Cards for Day 2 feedback \\
\hline
\end{tabular}

- Week 2 Teacher Practicum: Week 2 serves as a practicum for teachers. It gives them the opportunity to put into action the EBL learning concepts that they have learned in week 1. Each teacher is required to select a course they will teach in the Fall semester, conceive an open-ended design project, and develop a lesson plan. At end of week 2, each teacher delivers a poster and a presentation to all teachers attending the summer course. Follow-ups during the following academic year are conducted to hear teachers experience and provide further help.

Teachers are recruited from urban schools such as the greater Boston area Public schools where the majority of students are underrepresented as shown Table 2.

Table 5. Demographics of Greater Boston School District Students

\begin{tabular}{|l|c|c|c|c|c|c|c|}
\hline \multirow{2}{*}{ Race/Gender } & \multicolumn{7}{|c|}{ \% of School District Students } \\
\cline { 2 - 8 } & Boston & Cambridge & Everett & Framingham & Randolph & Revere & State \\
\hline $\begin{array}{l}\text { African } \\
\text { American }\end{array}$ & 45.5 & 39.1 & 10.9 & 7.3 & 45.0 & 4.9 & 8.9 \\
\hline Hispanic & 31.2 & 14.8 & 18.0 & 18.0 & 6.9 & 26.2 & 11.8 \\
\hline $\begin{array}{l}\text { Native } \\
\text { American }\end{array}$ & 0.4 & 0.6 & 0.2 & 0.3 & 0.3 & 0.3 & 0.3 \\
\hline Female & 48.6 & 47.7 & 48.5 & 50 & 48.3 & 48.1 & 48.5 \\
\hline $\begin{array}{l}\text { Total } \\
\text { Enrollment }\end{array}$ & 57,742 & 6,183 & 5,347 & 8,065 & 3,628 & 5,613 & 975,911 \\
\hline
\end{tabular}




\section{Findings/Results}

The EBL concept was piloted to 90 teachers over three year period during the NSF grant. Teachers have reported excellent results. We provide sample projects and feedback.

The physics teachers in one high school embraced the idea of imbedding project based learning into our daily activities. The teachers decided on a project centered on the creation of a mouse trap powered car that could go 10 meters. Teachers created project description, deliverables, required material, and a timeline for the students to follow. The idea behind the project is for the students to use physics principles and concepts and apply the related equation to drive the powered car as far as possible. Teachers guided the students through the steps of the EDP. Students build prototypes of their final design. Student teams show cased their prototypes in a one-day competition. Figures 2 show different car designs.

\section{Figure 2. Mouse Trap Powered Car Models}
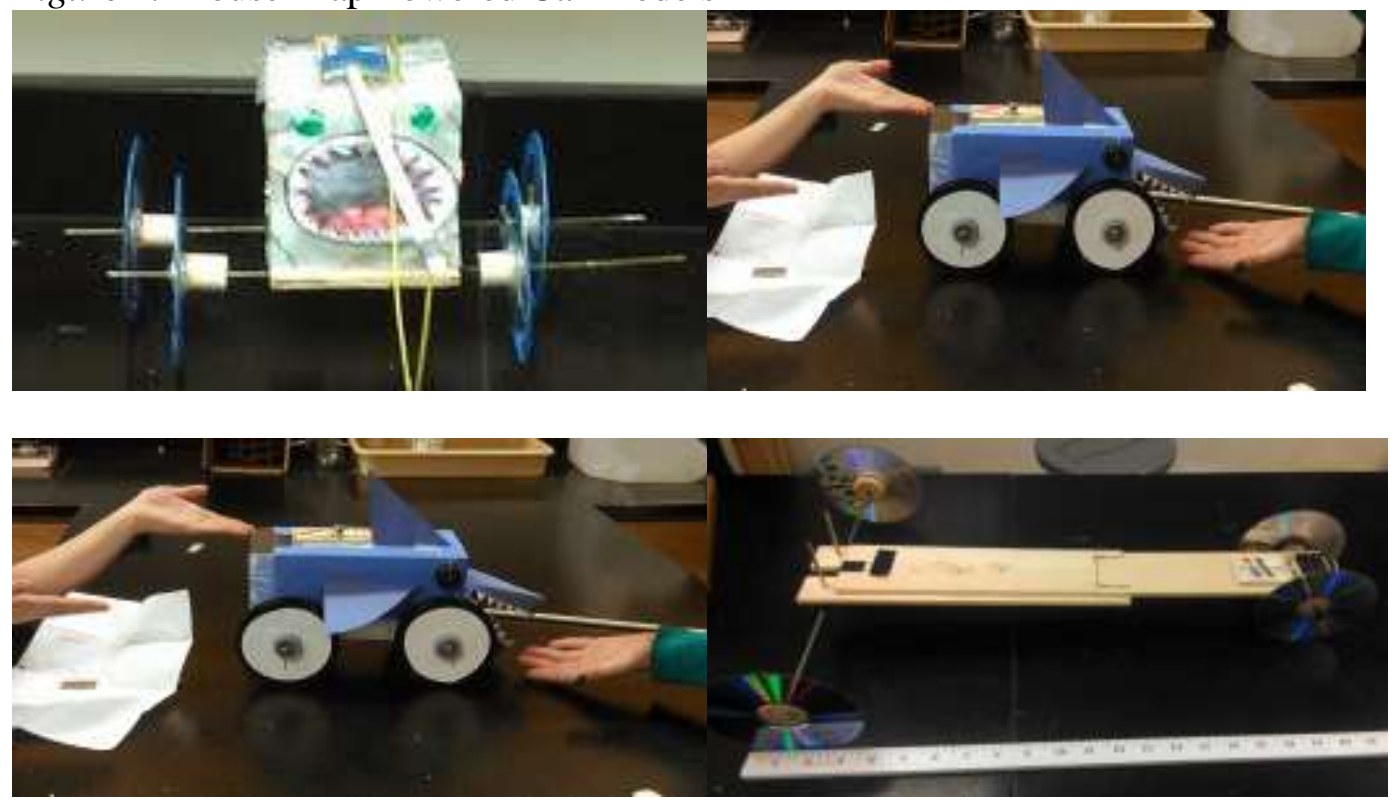

Other teachers in another school decided to create a robotics course, which fully embedded EBL into the curriculum. The goal of this robotics course is twofold: 1) Combine engineering, math, science, and art/creativity into one course; and 2) engineering-based learning can impact the way students learn STEAM principles, retain STEAM theory, and apply them to real world, relevant applications.

The initial implementation plans for the robotics course design along with a course syllabus were presented to the school administration for approval. Curriculum design was focused on designing a robotics course that would attract students who were historically uninterested in math and science to this type of course. The focus of this robotics course was to expose students to explore circuitry with snap circuit ROVS. Students would further experience the true design process through learning and using Solidworks ${ }^{\mathrm{TM}}$. 
In the Fall semester following course approval, teachers introduced two new semester course electives to the STEAM program. Both were hybrid robotics and EBL, engineering specific courses. The courses were an introduction to the engineering design process and how engineering can lead to various careers in math, science, and biotechnology. We had surveyed upcoming freshmen and sophomores in the spring to gather where their interests lie concerning science and engineering. The results of that survey indicated that students wanted a robotics program and would be more open to trying EBL courses if we offered one. Figure 3 shows different robots designs.

Figure 3. Robot Models

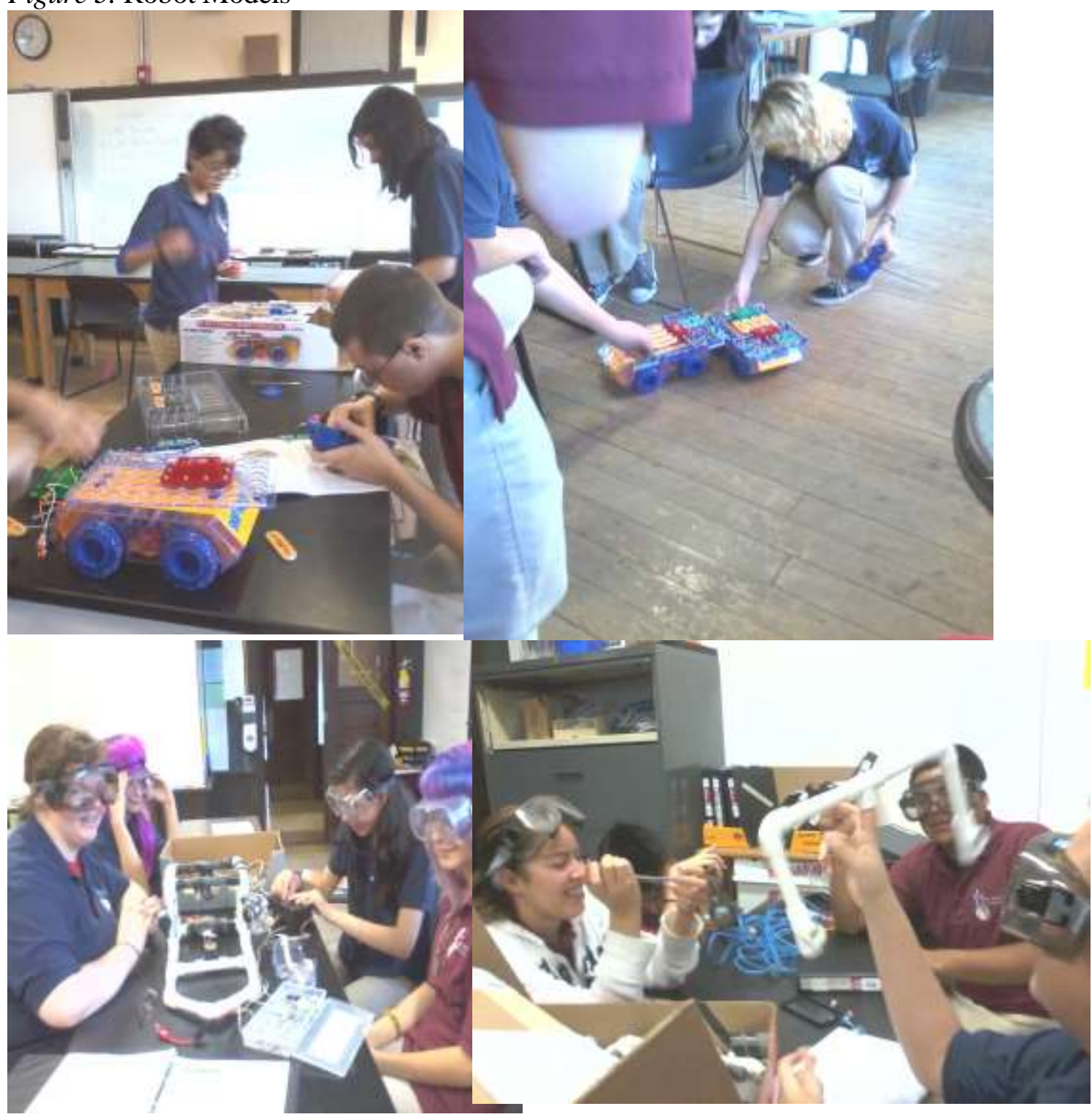




\section{Evaluation}

The project results were analyzed by an independent external evaluator as a requirement of the funding agency, NSF. The University of Massachusetts Donahue Institute served as the external evaluator of the project.

The evaluation design integrated a mixed-methods approach into an objective-based evaluation, yielding quantitative and qualitative data that will serve both formative and summative purposes. The evaluation is structured to measure the effectiveness of: (1) summer professional development (PD) for STEM teachers; and (2) EBL pedagogy in classroom STEM teaching. A comprehensive evaluation of the research program and its activities occurred over the three-year grant period. Both quantitative and qualitative methods were employed to collect evaluation data and provide formative feedback and summative evaluation of the grant's goals and objectives.

To assess the effectiveness of the summer PD in achieving its goals, all teachers participated in content-specific pre- and post-tests related to the materials and activities they are presented with during week 1 (i.e. fundamentals of technology, EDP, and project-based learning skills). These pre- and post-tests were developed by the professional development instructor with the assistance of the external evaluator. At the end of week 1 teachers will also be asked to complete a survey related to their perceptions of the training and their levels of preparedness for the following week.

During week 2, each participating teacher practiced integrating the skills they learned during week 1 to solve a specific STEM project problem, design and build a prototype, and present their designs to an audience of STEM professionals. An overall evaluation of the summer workshop experience was administered to all teachers at the end of the two-week period to assess teachers' understanding of how to implement newly acquired knowledge, materials, and activities into their classrooms.

In addition to pre- and post-surveys, focus groups of randomly selected group of 10 teachers were conducted. The goal is to capture the qualitative value of the research and concepts that are hard to articulate quantitatively in survey questions.

Data collection for the evaluation of the research project included teacher preand post-surveys during the summer course; two focus groups, one at the end of the summer course and one in April of the subsequent school year; a final survey for all cohorts at the end the grant period; and a student survey. These data collection activities for the evaluation are described below. All instruments were designed collaboratively by UMass Donahue Institute researchers and the research team.

The pre-survey, conducted on the first morning of the summer PD, asked teachers to provide demographic and background information including sex, ethnicity, subjects and grades taught, and full-time equivalent years as a certified teacher. Teachers also rated their prior level of experience with the course's main topics of the engineering design process, computer-aided design, capstone projects, and the manufacturing process. Finally, it included multiple-choice 
assessment items as an objective measure of teachers' knowledge in these four domains.

The post-survey, conducted on the last day of the summer PD, asked teachers to rate the usefulness of several major course components, the course's success on a range of intended outcomes, and the quality of aspects such as presenter preparedness and time provided for collegial exchange. The post-survey also included the same content knowledge items as the pre-survey, so that gains across the 10 days of the PD could be assessed. Finally, three open-ended items asked teachers to describe what aspects of the PD they found most valuable, what they would recommend changing, and any other comments or suggestions they might have.

On the final day of each PD, teachers participated in a one-hour focus group with a UMass Donahue Institute researcher. Discussion focused on components of the course they felt would most benefit their teaching practice, which aspects they found most challenging or frustrating, how prepared they felt to implement engineering capstone projects in their classrooms, supports they anticipated needing during the school year, and advice for teachers who take the course in the future. The transcripts of the focus groups were analyzed to identify common themes and divergent views.

During the spring callback day, teachers participated in a focus group with a UMass Donahue Institute researcher to discuss a range of topics related to the implementation of EBL activities and capstone projects in their classrooms.

During spring of year 3 of the project, a final survey was administered to all participants in the three-year program. This survey consisted of 28 multiple-choice and open-ended questions to learn about teachers' experiences implementing EBL-based activities in their classrooms, such as: the perceived effectiveness of the course in providing the knowledge needed to implement, implementation experiences, barriers to implementation, effect on student learning and interest in STEM, and activities/contact the participant would like to continue with Northeastern University's STEM Center.

Participant teachers were asked to administer two surveys to their studentsone pre-survey and one post-survey. The pre-survey collected data concerning students' interests in STEM fields, their attitudes toward certain processes, and their awareness of multiple aspects of STEM. The survey also included an eightquestion content-based test of knowledge. The post-survey included all of presurvey questions, as well as four additional questions concerning capstone experiences. A total of 721 surveys were collected: 64 from Cohort 1, 281 from Cohort 2, and 426 from Cohort 3.

Survey responses were analyzed using descriptive statistics. To assess growth across data points on attitude questions, chi square analyses the non-parametric Wilcoxon signed ranks test were performed to determine whether there are a statistically significant differences between pre- and post-test scores.

To assess growth on teacher and student pre-post content questions, pairedsamples t-tests were performed to determine if there were statistically significant differences between the scores. 
Statistically significant differences in the distributions are indicated by a probability level of significance (p) that is equal to or less than .05. Statistical significance refers to the probability that differences between pre-survey and postsurvey distributions are not due to chance and may be attributable to the intervention.

Open-ended responses were analyzed using a standard qualitative technique that involved multiple readings of the data set and assignment of themes around recurring ideas. Once themes were identified, each response was coded by its appropriate theme. Coded responses were then analyzed in their thematic groupings to identify patterns.

The participating teachers reported teaching included physics (43\%), engineering (40\%), technology (30\%), mathematics (25\%), biology (19\%), chemistry (15\%), environmental science (13\%) and "other subjects" (21\%). Two respondents reported teaching robotics, two anatomy and physiology, and another two computer science. Each of the following was taught by one teacher: earth science, forensic science, and oceanography. See Table 6.

Table 6. Subjects Taught by Participants

\begin{tabular}{|l|c|c|l|c|c|}
\hline \multicolumn{7}{|l|}{ Table 2. Subjects Taught by Participants } \\
\hline Physics & $\mathbf{n}$ & $\%$ & & $\mathrm{n}$ & $\%$ \\
\hline Engineering & 36 & $43 \%$ & Environmental Science & 11 & $13 \%$ \\
\hline Technology & 34 & $40 \%$ & Anatomy and Physiology & 2 & $2 \%$ \\
\hline Mathematics & 25 & $30 \%$ & Computer Science & 2 & $2 \%$ \\
\hline Other subjects & 22 & $26 \%$ & Robotics & 2 & $2 \%$ \\
\hline Biology & 18 & $21 \%$ & Earth Science & 1 & $1 \%$ \\
\hline Chemistry & 16 & $19 \%$ & Forensic Science & 1 & $1 \%$ \\
\hline
\end{tabular}

$n=84$. Respondents could select more than one subject.

Years of experience of teachers ranged from 1 to 35 years, with more than half of them having 7 or more years of experience. The average number of years was nine, and the modal number of years was three.

Grade levels taught by participants included $9^{\text {th }}(63 \%), 10^{\text {th }}(58 \%), 11^{\text {th }}$ $(74 \%)$, and $12^{\text {th }}(76 \%)$, with many of the respondents teaching multiple grades (Table 7).

Table 7. Grade Levels Taught by Participants

\begin{tabular}{|l|c|c|}
\hline \multicolumn{2}{|c|}{ Table 3. Grade Levels Taught by Participants } \\
\hline & $n$ & $\%$ \\
\hline Grade $\ominus$ & 53 & $63 \%$ \\
\hline Grade 10 & 49 & $58 \%$ \\
\hline Grade 11 & 62 & $74 \%$ \\
\hline Grade 12 & 64 & $76 \%$ \\
\hline Other grades & 13 & $15 \%$ \\
\hline
\end{tabular}

$n=84$. Respondents could select more than one grade. 
Figures 8-12 Show sample survey results of teachers.

Figure 8. Teachers Motivation due to Summer PD

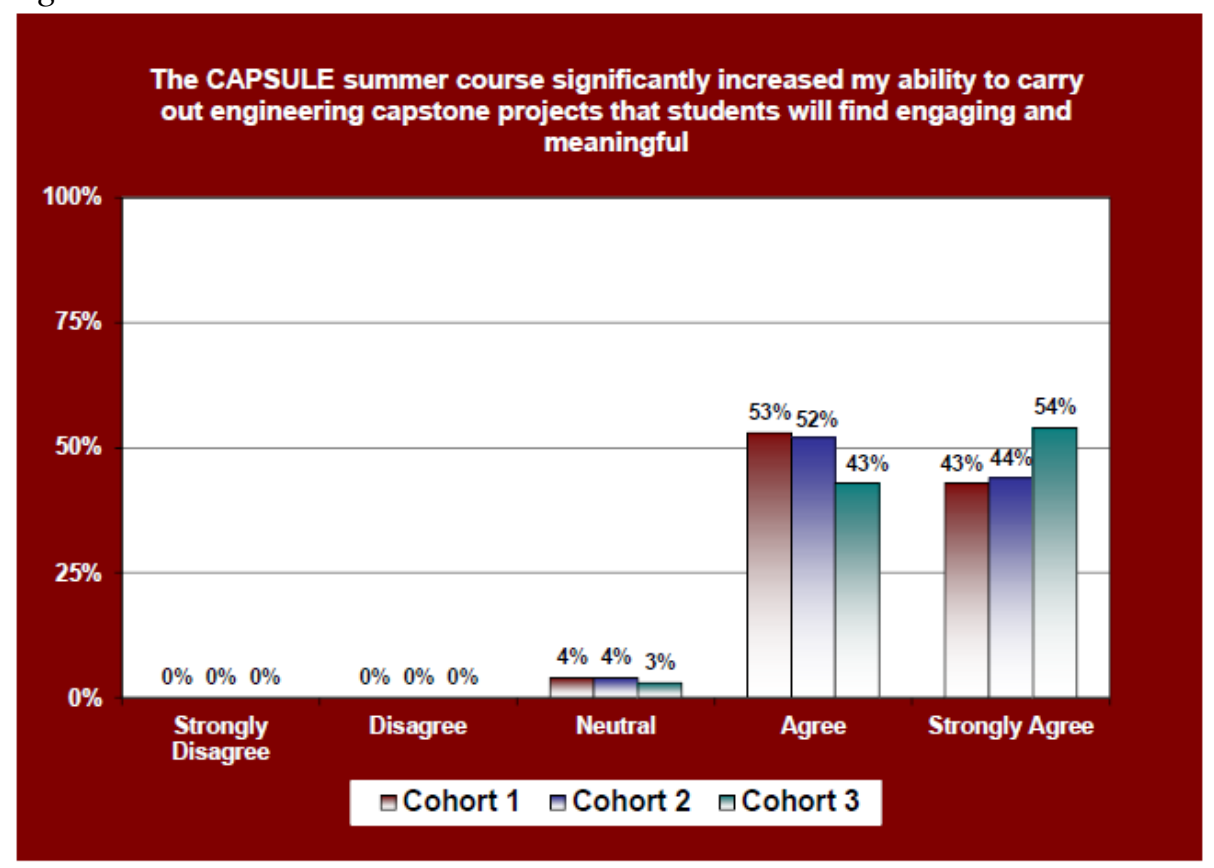

Figure 9. Teachers Intention to Use EBL in STEM Classroom Teaching

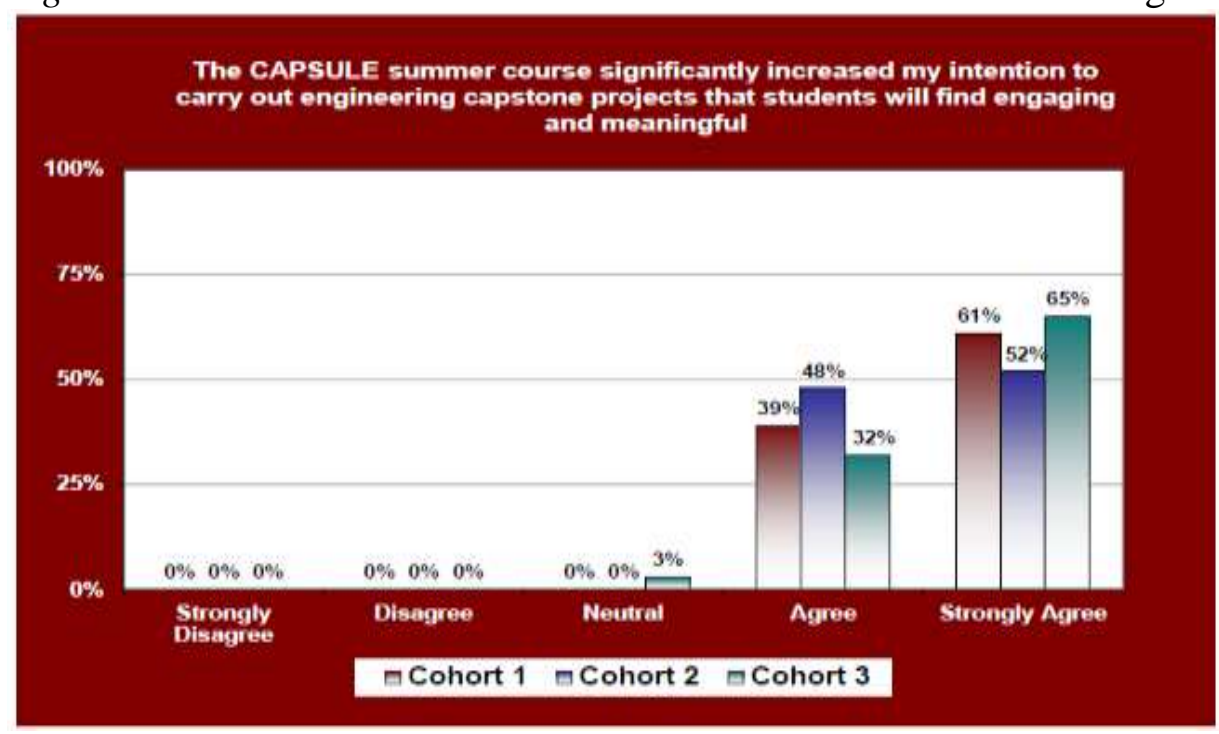


Figure 10. Teachers View on EBL Effectiveness

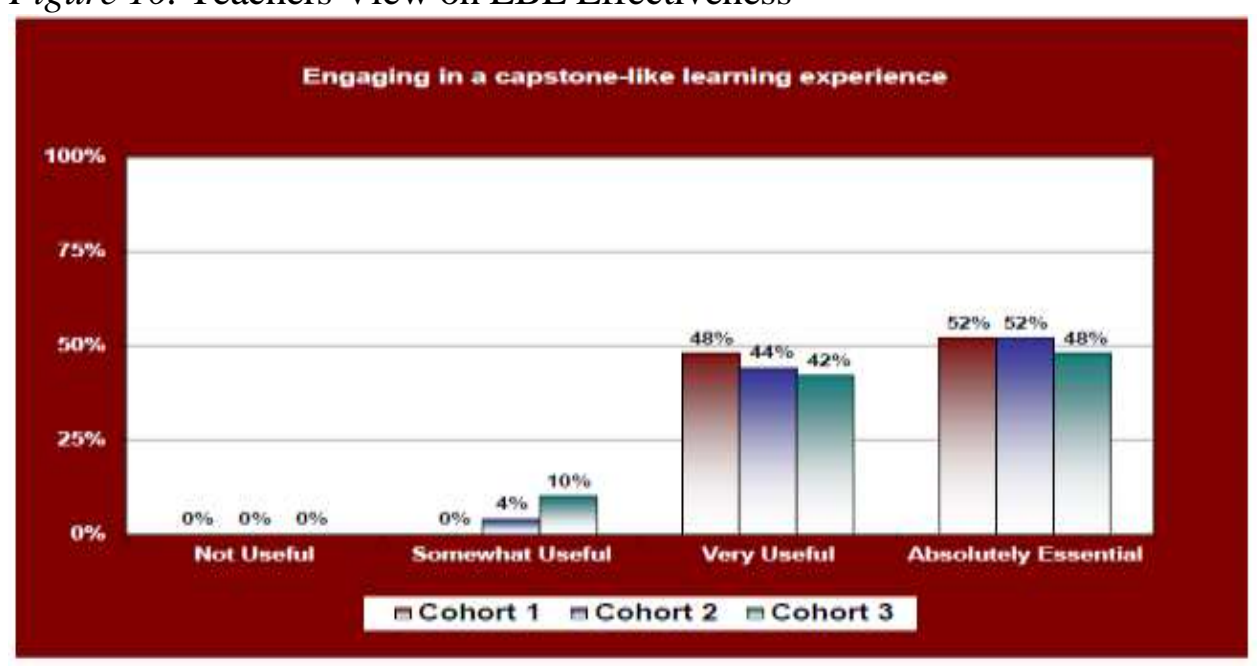

Figure 11. Effectiveness of Summer Professional Development

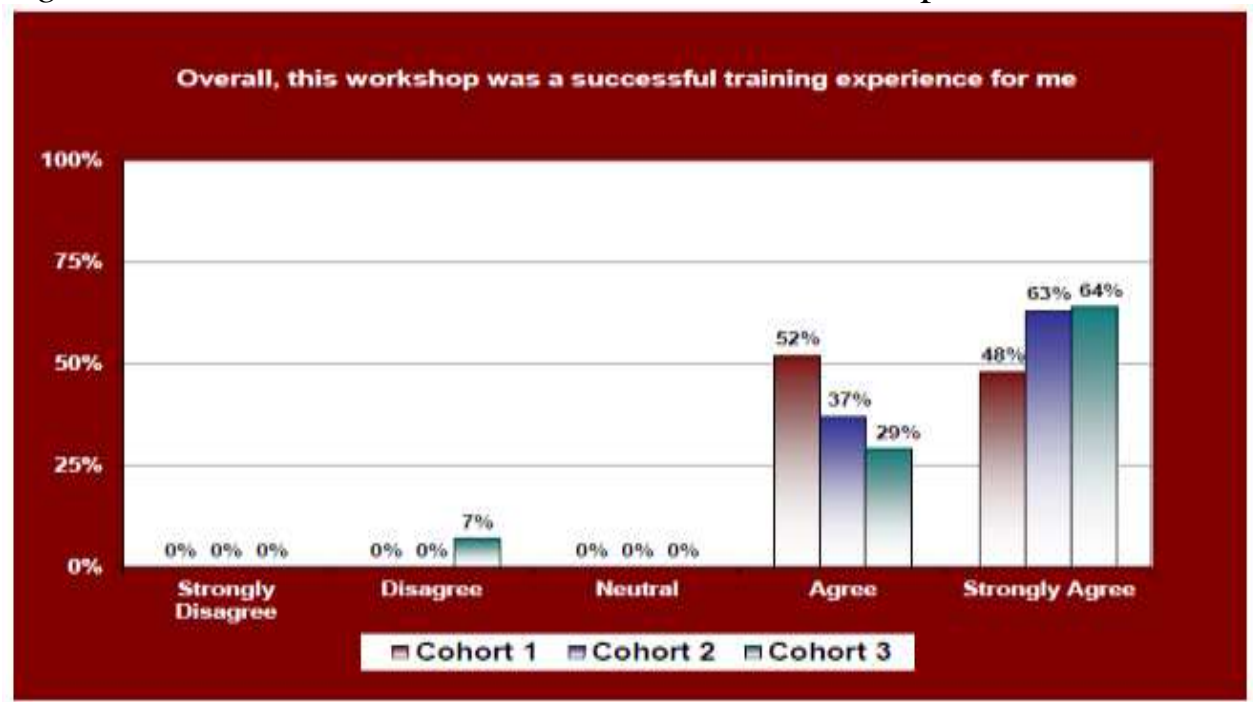

Figure 12. Effectiveness of Summer Professional Development

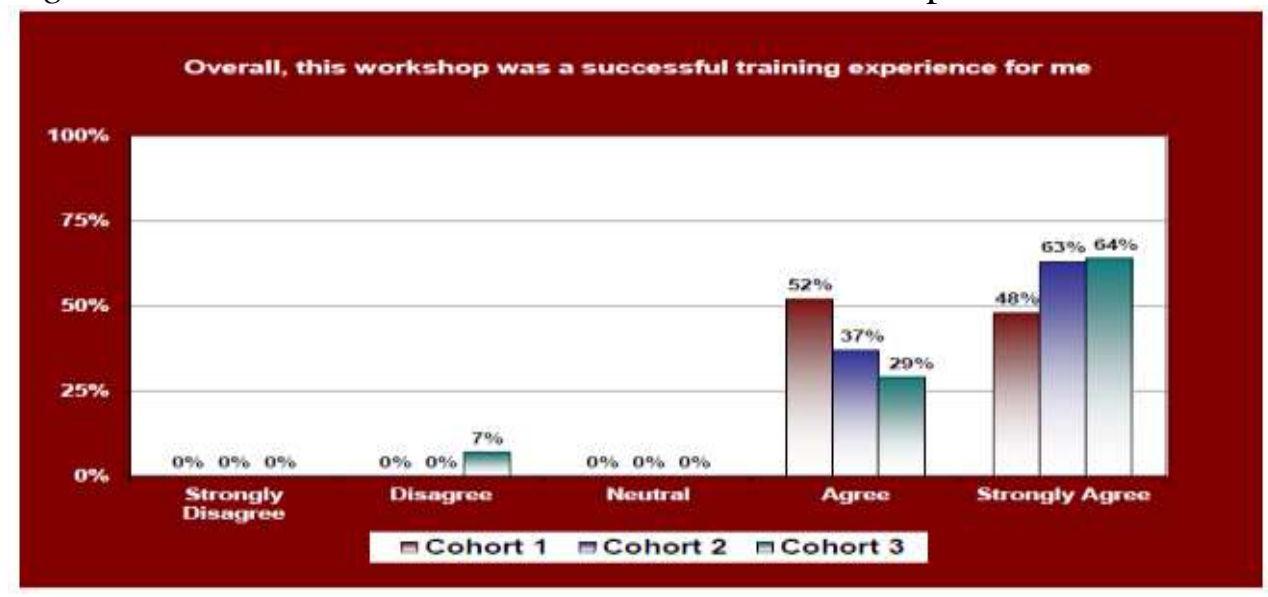


The results of the three focus groups over the project three years were mostly positive. Here is the summary of the third year focus group. When asked for other comments and suggestions, 18 respondents provided a variety of thoughts, though many served to underline previous comments. Four of the $18(22 \%)$ addressed the need for more time, including one suggestion that the course be three weeks long and two suggestions that more time be provided for engagement in a reflective process. Another four respondents addressed issues of organization, with two noting that the expectations were unclear and another commenting that it seemed like the instructor "phoned it in." Positive remarks came from three respondents, two noting that it was among the best PD in which they had participated and the third stating that it was the "best educational experience of my 20+ years of teaching." One participant noted liking that the professor adjusted his lectures in response to participants' comments, and one mentioned looking forward to call back days.

Teachers were asked about the impact of EBL on their students STEM learning experience. The majority of respondents across all cohorts agreed or strongly agreed that students in their classes were more interested in STEM after completing a capstone project (66\%); $21 \%$ neither agreed nor disagreed, and 5\% disagreed; no teacher strongly disagreed. The majority of respondents across all cohorts also agreed or strongly agreed that students are motivated to complete their capstone projects (71\%), with 18\% neutral, and 3\% in disagreement.

Nearly half $(47 \%)$ of respondents across all cohorts agreed or strongly agreed that EBL training made their engagement with high needs students more effective. Cohorts 1 and 2 tended to be more positive, with $64 \%$ and $62 \%$ respectively, while only $21 \%$ of Cohort 3 agreed or strongly agreed. However, $36 \%$ of Cohort 3 respondents neither agreed nor disagreed, which may indicate their lack of opportunity to engage with high needs students since they completed the EBL program.

Student surveys included attitude questions about interest, enjoyment, confidence, and awareness. Responses were analyzed by cohort to determine whether there were any statistically significant differences between the pre- and post-survey responses. For example, an analysis of Cohort 3 surveys indicates that although there were mean gains on some items, only one was statistically significant. Students enrolled in classes taught by Cohort 3 teachers were found to have a statistically significant increase in their agreement with the item, "I know what a capstone project/experience is" ( $29 \%$ to $59 \%, \mathrm{p}<.01)$. Additionally, when students were asked about their preferred mode for learning hard sciences (engineering, math, physical sciences), approximately two-thirds of students selected a combination rather than either lecture (teacher presents material in front of class) or project-based (learning through hands-on projects and experiments).

Student surveys showed many increases in interest and awareness of STEM subjects. Some indicated increased interest in learning about STEM subjects, finding out how things work, working in teams to solve open-ended projects, and learning how classroom concepts and theories are used in the real world. Many reported that doing projects and designing experiments helps them to understand STEM concepts and that classroom teaching and learning is more effective with 
capstone projects than without. Students also reported an increased understanding of EDP and how it is used, what an open-ended problem is, and what a capstone project is. Students were asked at post-survey about their capstone experience. About three-quarters felt the capstone project was very positive and about twothirds felt the capstone experience helped them understand STEM subjects and courses. About half agreed that the capstone projects made STEM more interesting. Perhaps most interesting, nearly half of students reported that the capstone experience and EDP made them think seriously about a STEM major in college.

\section{Discussion}

Incorporation of EBL into high school STEM curriculum works very effectively. Student interest has encouraged teachers to inquire about EBL training for cross curriculum lessons. Schools continue to collaborate and create partnerships with other schools, industry, and postsecondary institutions to offer other courses. High school teachers are working on incorporating EBL at the middle school level as an introductory for our high school programs. Other schools will be creating more engineering courses and integrating more engineering in core classes in the future. A chemistry teacher is using EBL as part of their chemistry class. EBL has inspired school administrations to budget for further teacher professional development and the incorporation of some type of "maker program" for their students.

What is more compelling to report is the lasting effect EBL has left on teachers and students long after the research has concluded. Here are some quotes from a teachers survey we have conducted

"They [students] are surprised to enjoy digital circuitry, and I even had a student become a computer engineering major after he developed an interest for it in my class."

"We have many more students entering College with a STEM field in mind."

"Students feel challenged but also very proud when they make something"

"Most students enjoy making presentations and presenting what they have learned."

"Students engage in real-world application of knowledge"

"Students like the independent nature of CAPSULE; it prepares them for college."

"Because of the rigor of the projects students must be engaged in the lesson taught. Also students develop strong problem solving skills as they design and improve upon their designs." 
"I think a big impact on my students has been in their ownership of their learning as they navigate the problem they are trying to solve."

\section{Conclusions}

Overall, the EBL project has been very successful in working with teachers to integrate engineering concepts into their STEM classes. Both teachers and their students report success through increased knowledge, tools, and extensive use of new resources, EDP, and capstone projects in classes. Introducing engineering to high school students has proven to be a valuable method to get them to appreciate and understand the abstract STEM concepts that discourage them. EBL makes implementing engineering in high school STEM courses that much easier due to its well defined structure and steps. The key to successful implementation of EBL in schools is to give schools the complete freedom to implement it. It could be one week long in a course, one semester long, one year ( 2 semesters) long, or it could be a full elective course. It all depends on the school specific needs and time allocated for engineering in school curriculum.

\section{Acknowledgments}

This work is supported by the National Science Foundation under grant numbers DRL 0833636. Any opinions, findings, and conclusions or recommendations expressed in this material are those of the author(s) and do not necessarily reflect the views of the National Science Foundation.

\section{References}

American Association of University Women. (AAUW) (2000). Tech-Savvy: Educating Girls in the New Computer Age. Washington, DC: AAUW Educational Foundation.

Berman, J. (2001). Employment Outlook 2000-10: Industry Output and Employment Projections to 2010. Monthly Labor Review November 2001.

Boston Redevelopment Agency. (BRA) (2001). Professional Services Fact Sheet, May 2001. Retrieved from https://bit.ly/2RDjUiZ. CIO Insight: Strategies for IT Business Leaders. (2007, April) Women in IT: Where Girls Aren't. Retrieved from https://bit.ly/2SU5tsl

Conley, C.H., Ressler, S.J., Lenox, T.A., \& Samples, J.W. (2000). Teaching Teachers to Teach Engineering. Journal of Engineering Education, 89(1), 31-38.

Daley, W. (1998, January 12). Speech of U.S. Commerce Secretary. Delivered at 1998 National Information Technology Workforce Convocation, Berkeley, California.

Dennis, N.D. (2001). ExCEEd Teaching Workshop: Taking It on the Road. 2001 ASEE Conference \& Exposition: Peppers, Papers, Pueblos, and Professors; Albuquerque, NM, 24-27.

Dym, C.L., Agogino, A.M., Eris, O., Frey, D.D., \& Leifer, L.J. (2005). Engineering Design Thinking, Teaching, and Learning. Journal of Engineering Education, 94(1), $103-120$. 
Gatta, M. (2001, May). Women and Work: Prospects for Parity in the New Economy. A report of the State Employment and Training Commission's Council on Gender Parity in Labor and Education. Center for Women and Work, Rutgers University.

Gatta, M., \& Trigg, M. (2001, May). Bridging the Gap: Gender Equity in Science, Engineering and Technology. A report of the State Employment and Training Commission's Council on Gender Parity in Labor and Education. Center for Women and Work, Rutgers University.

Guild, P.B. (2001). Diversity, Learning Style and Culture. New Horizons for Learning. Retrieved from https://bit.ly/2G71KYl. Adapted from Marching to Different Drummers by Pat Burke Guild and Stephen Garger, ASCD, $2^{\text {nd }}$ edition, 1998.

Hale-Benson, J.E. (1986). Black children: Their roots, culture, and learning style (rev. ed.). Baltimore: Johns Hopkins University Press.

Hilliard, A.G. (1989, January) Teachers and cultural styles in a pluralistic society. NEA Today, 7(6), 65-69.

Ktoridou, D., \& Doukanari, E. (2016). Promoting Multidisciplinary Collaboration through a Challenge-Based Virtual Learning Environment. In J. Whatley \& C. Nerantzi (Eds.), Teaching with Team Projects in Higher Education (pp.61 - 71). Informing Science.

Massachusetts Department of Education. (2003, September) Massachusetts Comprehensive Assessment System, Summary of District Performance.

National Research Council. (NRC) (2001). Committee on Workforce Needs in Information Technology. Building a Workforce for the Information Economy, National Academy Press, Washington, DC, October 2001.

National Science Foundation. (NSF) (2003, August). New Formulas for America's Workforce: Girls in Science and Engineering, NSF03207. Project-Based Learning Research. Retrieved from https://bit.ly/2WFLsIw.

Shade, B.J. (1989). The influence of perpetual development on cognitive style: Cross ethnic comparisons. Early Child Development and Care, 51(1), 137-155.

U.S. Department of Labor. (1991, June). The Secretary's Commission on Achieving Necessary Skills. What Work Requires of Schools: A SCANS Report for America 2000.

U.S. Department of Labor. (2000). Occupational Outlook Handbook, 2000-01 Edition. Bureau of Labor Statistics.

Winschitl, M., \& Sahl, K. (2002). Tracing teachers' use of technology in a laptop computer school: The interplay of teacher beliefs, social dynamics, and institutional culture. American Education Research Journal, 39(1), 165-205.

YESICT EU project 2018, Pedagogical Methodology: A modified Challenge-based Learning with Design Thinking. http://yesict.eu/\#methodology 
